\title{
KOBENOMYCIN, A NEW POLYPEPTIDE ANTIBIOTIC
}

\author{
Saburo Okamoto, Mikao Mayama, Yu Tanaka, \\ Katsuya Tawara, Noboru Shimaoka, Hiroshi Kato, \\ Haruo Nishimura, Mitsuo Ebata and Hideo Ohtsuka \\ Shionogi Research Laboratory, Shionogi \& Co., Ltd., Fukushima-ku, Osaka, Japan
}

(Received for publication January 21, 1968)

\begin{abstract}
A new colorless crysalline polypeptide antibiotic, kobenomycin, has been isolated from the culture broth of Streptomyces kobenensis, nov. sp. The morphological, cultural and physiological characteristics of this organism, and the isolation and properties of the new antibiotic are described. Kobenomycin is highly active only against aerobic sporulating bacilli and moderately active against acid-fast bacilli and protozoa. No activity was observed against the other bacteria and fungi. The antibiotic is toxic to mice and hemolytic to rabbit red cells.
\end{abstract}

A colorless crystalline antibiotic, active against aerobic spore-forming bacilli, acidfast bacilli and protozoa, has been isolated from the broth of a strain of Streptomyces. This strain, which is indexed M-88 in our culture collection, was isolated from a soil sample collected from Kobe City. The antibiotic, which we have named kobenomycin, is a polypeptide.

\section{Characterization of the Streptomyces M- 88}

Cultures of Streptomyces M-88 were incubated on each medium at $28^{\circ} \mathrm{C}$ for 18 days. The morphological properties of the strain were observed on BENNETT's agar and detailed observations were made with agar-cylinder culture method ${ }^{1)}$. The structure of the spore surface was observed with the electron microscope. Aerial mycelium of a cottony type is formed abundantly on BENNETr's agar. The sporophores are straight and branch in biverticillus type. The spores are formed in chains with $5 \sim 10$ conidia. The spore is cylindrical to ellipsoidal in shape $(0.6 \mu$ in width, $1.0 \sim 1.5 \mu$ in length) with a smooth surface. Sporangium and flagellated spore are not observed and also fragmentation and sclerotia in substrate mycelium are not observed.

The cultural and physiological characteristics of this strain are listed in Tables 1 and 2. The utilization of carbon sources by this strain is shown in Table 3.

From the results of these studies, the characteristics of Streptomyces M-88 can be summarized as follows: Sporophores are straight in biverticillus type (secondary whorl). Structure of spore surface is smooth and shape of spore is cylindrical to ellipsoidal. Production of melanoid pigment and tyrosinase reaction are negative. Growth type on glucose broth is ring type. Acid production from glucose is positive. Good growth is observed at $28^{\circ} \mathrm{C}$ and $37^{\circ} \mathrm{C}$, and 'fair growth was observed at $45^{\circ} \mathrm{C}$. Color of aerial mycelium is white to yellowish gray, substrate mycelium is colorless 
Table 1. Cultural characteristics of Streptomyces M-88

\begin{tabular}{|c|c|c|c|c|c|}
\hline \multirow{2}{*}{ Medium } & \multirow{2}{*}{ Growth } & \multirow{2}{*}{$\begin{array}{l}\text { Formation } \\
\text { of aerial } \\
\text { mycelium }\end{array}$} & \multicolumn{3}{|c|}{ Color } \\
\hline & & & Aerial mycelium & Substrate mycelium & $\begin{array}{l}\text { Soluble } \\
\text { pigment }\end{array}$ \\
\hline CzaPEK's agar & Poor & $\begin{array}{l}\text { Fair to poor } \\
\text { cottony }\end{array}$ & White & White to yellowish gray & None \\
\hline $\begin{array}{l}\text { Glucose-CzAPEK's } \\
\text { agar }\end{array}$ & Poor & Poor & Yellowish gray & $\begin{array}{l}\text { Yellowish gray to pale } \\
\text { yellow }\end{array}$ & None \\
\hline Cellulose agar & $\begin{array}{l}\text { Poor to } \\
\text { scant }\end{array}$ & Poor cottony & White & Colorless & None \\
\hline Starch agar & Poor & Poor & White & Colorless & None \\
\hline Ca-malate agar & Fair & Poor & $\begin{array}{l}\text { Pale yellow to } \\
\text { yellowish gray }\end{array}$ & Dull yellow & None \\
\hline $\begin{array}{l}\text { Glucose- } \\
\text { asparagine agar }\end{array}$ & Fair & $\begin{array}{l}\text { Poor to } \\
\text { scant }\end{array}$ & Pale yellow & $\begin{array}{c}\text { Dull yellow to pale } \\
\text { yellowish brown }\end{array}$ & None \\
\hline $\begin{array}{l}\text { Glucose-peptone } \\
\text { agar }\end{array}$ & Good & $\begin{array}{l}\text { Fair } \\
\quad \text { powdery }\end{array}$ & Yellowish gray & Dull yellow & None \\
\hline Nutrient agar & Good & Good & White & $\begin{array}{l}\text { Pale yellowish brown } \\
\text { to yellowish brown }\end{array}$ & None \\
\hline $\begin{array}{l}\text { Glucose-bouillon } \\
\text { agar }\end{array}$ & Good & Good & White & Yellowish brown & None \\
\hline BENNETT's agar & Good & Good, cottony & Yellowish gray & Yellowish brown & None \\
\hline Glucose-broth & Good & Good, cottony & White & Pale yellowish brown & None \\
\hline Potato & Fair & Poor & $\begin{array}{l}\text { Yellowish gray to pale } \\
\text { yellow }\end{array}$ & Dull yellow & None \\
\hline $\begin{array}{l}\text { Glucose-CzAPEK's } \\
\text { solution }\end{array}$ & Scant & & Yellowish gray & Pale yellowish brown & None \\
\hline Milk & Good & Poor & Yellowish gray & Pale yellowish brown & None \\
\hline Gelatin & Good & Poor & Brownish white & Grayish brown & Dark brown \\
\hline $\begin{array}{l}\text { Growth response } \\
\text { to temperature }\end{array}$ & \multicolumn{5}{|c|}{$\begin{array}{l}\text { Good growth at } 28^{\circ} \mathrm{C} \text { and } 27^{\circ} \mathrm{C} \text {. Fair growth at } 45^{\circ} \mathrm{C} \text {. Fair sporulation at } \\
28^{\circ} \mathrm{C}, 37^{\circ} \mathrm{C} \text { and } 45^{\circ} \mathrm{C} \text {. }\end{array}$} \\
\hline $\begin{array}{l}\text { Growth type in } \\
\text { glucose-broth }\end{array}$ & & & & & \\
\hline
\end{tabular}

to yellowish on synthetic media. Color of aerial mycelium is white to yellowish gray, substrate mycelium is yellow to yellowish brown on organic media. Soluble pigment is not produced on synthetic and organic media. Reduction of nitrate is positive.

Among many species of Streptomyces described in BERGEY's Manual of Determinative Bacteriology, 1957, 7 Ed. ${ }^{2}$, WaksMAN's “The Actinomycetes" 1961, Vol. 23), and other literature, Streptomyces M-88 is closely related to Streptomyces mashuensis in morphological properties (straight biverticillus), color of substrate mycelium (yellowish), lack of soluble pigment on synthetic and organic media, growth type on glucose broth and some biochemical properties such as melanoid pigment (negative), tyrosinase reaction (negative), starch hydrolysis, gelatin liquefaction and milk peptonization (positive). This strain was then compared in detail with Streptomyces mashuensis, and after actual comparison, it was recognized that Streptomyces M-88 differed from
Table 2. Physiological properties of Streptomyces $\mathrm{M}-88$

\begin{tabular}{l|l}
\multicolumn{1}{c|}{ Property } & Results \\
\hline Formation of melanoid pigment & Negative \\
Tyrosinase reaction & Negative \\
Acid formation from glucose & Positive \\
Starch hydrolysis & Positive \\
Nitrate reduction & Positive \\
Gelatin liquefaction & Positive \\
Milk peptonization & Positive \\
Cellulose reaction & Negative \\
\hline
\end{tabular}


Table 3. Utilization of carbon sources by Streptomyces $\mathrm{M}-88$ on the basal medium of Priduam et $a l$.

\begin{tabular}{|c|c|c|c|}
\hline Carbon sources & Result & Carbon sources & Result \\
\hline Glucose & If (Good growth) & $d-\mathrm{Xylose}$ & \pm \\
\hline Glycerine & H & d-Mannitol & \pm \\
\hline$d$-Mannose & H & Rhamnose & \pm \\
\hline d-Fructose & $H$ & Raffinose & \pm \\
\hline Inositol & H & Dulcitol & \pm \\
\hline Soluble starch & + (Fair growth) & Inulin & \pm \\
\hline Potato starch & + & l-Arabinose & - (No growth) \\
\hline Dextrin & + & Salicin & - \\
\hline Lactose & + & Sorbose & - \\
\hline Maltose & + & Sorbitol & - \\
\hline Galactose & + & $d$-Mannitol & $一$ \\
\hline Sucrose & \pm (Faint growth) & Cellulose & 一 \\
\hline
\end{tabular}

Table 4. Distinguishable characteristics between Streptomyces M-88 and Streptomyces mashuensis based on actual comparison

\begin{tabular}{|c|c|c|c|}
\hline Property & Medium & Streptomyces M-88 & Streptomyces mashuensis \\
\hline $\begin{array}{l}\text { Acid production } \\
\text { from glucose }\end{array}$ & & Positive & Negative \\
\hline \multirow{3}{*}{ Growth } & CzapeK's agar & Poor & Good \\
\hline & Glucose-CzapeK's agar & Poor & Good \\
\hline & Starch agar & Poor & Good \\
\hline \multirow{5}{*}{$\begin{array}{l}\text { Aerial mycelium } \\
\text { formation }\end{array}$} & CzAPEK's agar & Fair & Scant to none \\
\hline & Ca-malate agar & Fair & None \\
\hline & Nutrient agar & Good & None \\
\hline & Glucose-bouillon agar & Good & Scant \\
\hline & Glucose-broth & Good & None \\
\hline $\begin{array}{l}\text { Color of aerial } \\
\text { mycelium }\end{array}$ & BENNETT's agar & Yellowish gray & Brownish white \\
\hline \multirow{3}{*}{$\begin{array}{l}\text { Color of substrate } \\
\text { mycelium }\end{array}$} & CzaPeK's agar & White to yellowish gray & Pale olive \\
\hline & Glucose-CzaPEK's agar & Yellowish gray & Pale olive \\
\hline & Starch agar & Colorless & $\begin{array}{l}\text { Pale olive to pale } \\
\text { yellowish brown }\end{array}$ \\
\hline \multirow{3}{*}{$\begin{array}{l}\text { Utilization of } \\
\text { carbon sources }\end{array}$} & Lactose & + (Fair growth) & - (No growth) \\
\hline & Galactose & & \\
\hline & Sucrose & \pm (Faint growth) & H (Good growth) \\
\hline
\end{tabular}

S. mashuensis in the following points: acid production from glucose; growth on CzAPEK's agar, glucose-CZAPEK's agar and starch agar; formation of aerial mycelium on CzAPEK's agar, calcium-malate agar, nutrient agar, glucose-bouillon agar and glucose broth; color of aerial mycelium on BENNETT's agar; color of substrate mycelium on CZAPEK's agar, glucose-CzAPEK's agar and starch agar; and utilization of lactose, galactose and sucrose. These results obtained are presented in Table 4.

Therfore, it was decided that Streptomyces $\mathrm{M}-88$ is a new species of Streptomyces and it was named Streptomyces kobenensis, nov. sp. 


\section{Production and Isolation of Kobenomycin}

Shake-flask fermentation of the kobenomycin-producing cultures was carried out according to the following procedure. An inoculum was prepared by growing a vegetative suspension of the culture on a reciprocal shaker for 48 hours at $28^{\circ} \mathrm{C}$. The medium used contained $2 \%$ glucose, $0.5 \%$ peptone, $0.5 \%$ meat extract, $0.3 \% \mathrm{NaCl}$, and $0.35 \% \mathrm{CaCO}_{3}(\mathrm{pH} 7.0)$.

A $3 \%$ inoculum was used to seed a production medium containing $2 \%$ potato starch, $3 \%$ soybean meal, $0.3 \% \mathrm{NaCl}$ and $0.35 \% \mathrm{CaCO}_{3}(\mathrm{pH} 7.2)$. The fermentations were carried out on a reciprocal shaker at $28^{\circ} \mathrm{C}$ for 7 days. The seed and production media described above were also used for antibiotic production in stirred-jar fermentors. Kobenomycin produced was determined by a paper disc or cup method using Bacillus subtilis PCI-219 as the test organism. Activity was found mainly in the culture filtrate. A typical fermentation in the above medium assayed about $200 \sim 400$ mcg per ml.

Kobenomycin could be removed from the fermentation broth by adsorption on active carbon or cation-exchange resin such as Amberlite IRC-50 and then by elution with aqueous acetone. A procedure for the preparation of kobenomycin is as follows: 20 liters of filtered fermentation broth ( $\mathrm{pH} 5.6$ ) were adjusted to $\mathrm{pH} 7.0$ with $10 \%$ sodium hydroxide and filtered. The filtrate was treated with active carbon $(0.5 \mathrm{~g}$ per $100 \mathrm{ml}$ ) which was removed by filtration. The filtrate was discarded and the carbon. was eluted two times by stirring for one hour with 5-liter portions of $80 \%$ aqueous acetone. Each extract was collected by filtration. The extracts were combined and concentrated in vacuo to an aqueous solution $(500 \mathrm{ml})$. The precipitate which occurred during the concentration was collected by filtration. Further purification of both precipitate and filtered solution were separately effected by chromatography on carbon. An equal weight of active carbon $(15 \mathrm{~g})$ and Hyflo Supercel ( $15 \mathrm{~g}$ ) was mixed and packed into a glass column $(3.4 \times 14 \mathrm{~cm})$. The precipitate $(5 \mathrm{~g})$ suspended in water (about 50 $\mathrm{ml}$ ) or the filtered solution was placed on the column and washed with water. Stepwise elution was carried out with aqueous acetone of $20 \%, 40 \%$ and $80 \%$. Kobenomycin was eluted with $80 \%$ aqueous acetone. The active fractions of $80 \%$ aqueous acetone were combined and concentrated in vacuo to precipitate the crude kobenomycin which was collected and dried in vacuo to give $2 \mathrm{~g}$ of colorless crude kobenomycin powder.

For crystallization, $2 \mathrm{~g}$ of the crude powder was suspended in $50 \mathrm{ml}$ of $80 \%$ aqueous methanol at $60^{\circ} \mathrm{C}$ and filtered. The residue was dissolved in $50 \mathrm{ml}$ of $50 \%$ aqueous methanol at $60^{\circ} \mathrm{C}$ and filtered. The filtrate was concentrated in vacuo to dryness. Crystalline kobenomycin ( $420 \mathrm{mg}$ ) was obtained by dissolving $640 \mathrm{mg}$ of the dried material in $50 \mathrm{ml}$ of $80 \%$ aqueous methanol at $60^{\circ} \mathrm{C}$ and allowing it to stand at room temperature. The crystalline kobenomycin was then recrystallized from the same solvent.

\section{Chemical and Physical Properties of Kobenomycin}

Kobenomycin is a colorless crystalline polypeptide antibiotic which contains sulfur. 
It is soluble in acetic acid, dimethylsulfoxide and pyridine, slightly soluble in water, methanol and ethanol, but insoluble in acetone, ether, petroleum ether and ethyl acetate. It melts at $285 \sim 288^{\circ} \mathrm{C}$ under decomposition.

Analytical data of kobenomycin dried at $60^{\circ} \mathrm{C}$ in vacuo to constant weight are as follows: C $51.93 \%, \mathrm{H} 6.53 \%, \mathrm{~N} 15.75 \%$, S $4.96 \%$. The specific rotation of kobenomycin is $[\alpha]_{\mathrm{D}}^{21.5}-87.5$ \pm 2 (c 1.0, glacial acetic acid). The ultraviolet absorption spectrum (Fig. I) is characterized by a maximum in water at $280 \mathrm{~m} \mu\left(\mathrm{E}_{1 \mathrm{~cm}}^{1 \%} 22.1\right)$ and shoulders at $220 \mathrm{~m} \mu, 275 \mathrm{~m} \mu$ and $285 \mu \mathrm{m}$; in $0.1 \mathrm{~N} \mathrm{HCl}$ at $280 \mathrm{~m} \mu\left(\mathrm{E}_{1 \mathrm{~cm}}^{1 \%} 260\right)$ and shoulders at $220 \mathrm{~m} \mu, 257 \mathrm{~m} \mu$ and $285 \mathrm{~m} \mu$; in $0.1 \mathrm{~N} \mathrm{NaOH}$ at $222 \mathrm{~m} \mu\left(\mathrm{E}_{1 \mathrm{~cm}}^{1 \%} 253\right)$ and shoulder at $270 \sim 280$ $\mathrm{m} \mu$. The infrared absorption spectrum of kobenomycin in $\mathrm{KBr}$ shows the following frequencies $(\mathrm{S}=$ strong, $\mathrm{B}=$ broad, $\mathrm{Sh}=$ shoulder) : $3300(\mathrm{~S}), 3072(\mathrm{~S}), 2959(\mathrm{~S}), 1664(\mathrm{~S}), 1525(\mathrm{~B})$, $1452(\mathrm{~B}), 1390(\mathrm{Sh}), \mathrm{I} 335(\mathrm{~B}), 1270(\mathrm{Sh})$ and $750(\mathrm{~S}) \mathrm{cm}^{-1}$ (Fig. 2).

Fig. 2. Infrared absorption spectrum of kobenomycin (KBr)

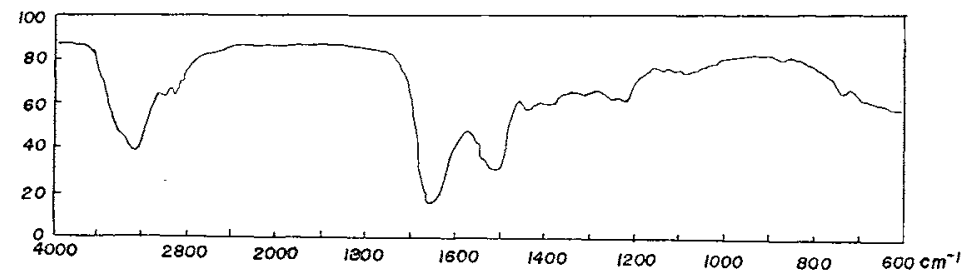

It gives positive Folin-phenol, ninhydrin, biuret, xanthoprotein and EHRLICH reactions. Anthrone, Fehling, Pauly, SAKaguchi and Molisch reactions are negative.

Rf values by ascending paper chromatography at room temperature using Toyo filter paper No. 51 are as follows : 0.60 with $t$-butanol-acetic acidwater $(2: 1: 1), 0.15$ with $n$-butanol-acetic acidwater $(4: 1: 5$, upper phase), and 0.83 with acetonewater $(1: 1)$.

On paper electrophoresis using Toyo filter peper No. 51 at 300 volt for 3 hours, kobenomycin moves slightly to cathode in the $\mathrm{pH} 2.0, \mathrm{pH} 5.0$, $\mathrm{pH} 6.0, \mathrm{pH} 7.0$ and $\mathrm{pH} 8.0$ buffer solutions. In $\mathrm{pH}$ 11.4 buffer solution, it moves slightly to anode.

$\mathrm{Rf}$ values by thin-layer chromatography using silica gel $\mathrm{G}(250 \mu)$ are as follows: 0.30 with $n$ butanol-acetic acid-water $(4: 1: 2), 0.50$ with $n$ -
Fig. 1. Ultraviolet absorption spectra E of kobenomycin

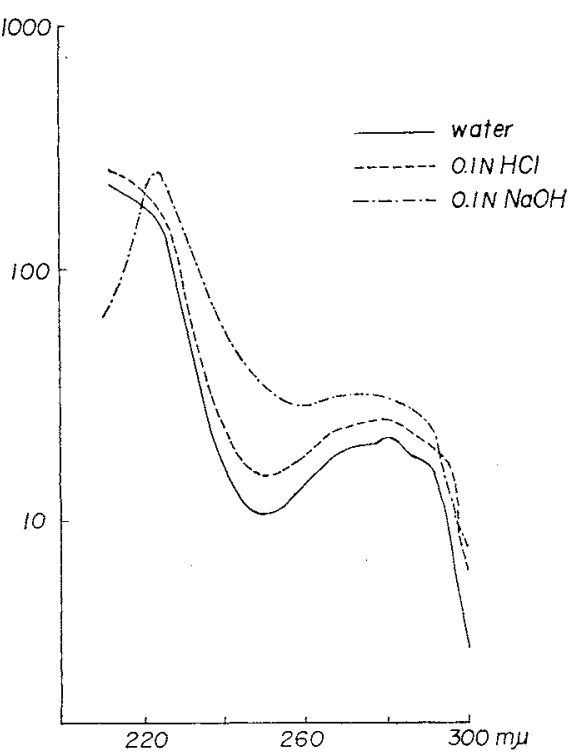


butanol-ethanol-0.1 N HCl ( $1: 1: 1), 0.75$ with $n$-butanol-pyridine-acetic acid-water (15: $10: 3: 10)$, 1.0 with $\mathrm{CHCl}_{3}-$ methanol-17\% $\mathrm{NH}_{4} \mathrm{OH}(2: 1: 1$, upper phase) and 0.57 with ethanol-water $(4: 1)$.

The presence of amino acids in kobenomycin was confirmed by paper chromatography of its acid and alkali hydrolysates. The amino acid composition of kobenomycin acid hydrolysate [ $6 \mathrm{~N}$ hydrochloric acid at $110^{\circ} \mathrm{C}$ for 24 hours] and alkali hydrolysate [barium hydroxide at $110^{\circ} \mathrm{C}$ for 24 hours] was determined quantitatively by an automatic amino acid analyzer. Tryptophane content was also determined by UV absorption method. The results were shown in Table 5. The molecular weight of kobenomycin was suggested to be $2,150 \sim 2,200$, from its amino acid composition.

\section{Biological Properties}

Antimicrobial activity: To determine the minimal inhibitory concentration of kobenomycin, the antibiotic was examined by the streak plate dilution method or by the tube dilution method. The antimicrobial spectrum of kobenomycin is fairly specific in its activity, aerobic sporulating bacilli are inhibited strongly, and also it is effective against acid-fast bacilli and some protozoa, such as Trichomonas vaginalis and Tetrahymena geleii. The other bacteria, yeast and fungi are not affected even at a concentration of 200 mcg per ml. Table 6 shows the minimal inhibitory concentration of kobenomycin for aerobic sporulating bacilli, acid-fast bacilli and protozoa.

Stability: Kobenomycin was dissolved in dimethylsulf oxide at $10 \mathrm{mg} / \mathrm{ml}$ and was diluted with sterile distilled water to give test solutions containing $1,000 \mathrm{mcg} /$ $\mathrm{ml}$. The test solutions were Table 6. Minimal inhibitory concentration of kobenomycin for aerobic spore-forming bacilli, acid-fast bacilli and protozoa

\begin{tabular}{l|c}
\hline \multicolumn{1}{c|}{ Test organisms } & $\begin{array}{c}\text { Minimal inhibitory } \\
\text { concentration } \\
\mathrm{mcg} / \mathrm{ml}\end{array}$ \\
\hline 1. Bacillus subtilius, PCI-219 & 5.0 \\
2. Bacillus anthracis & 1.0 \\
3. Bacillus megatherium & 5.0 \\
4. Bacillus cereus & 0.5 \\
5. Bacillus agri & 1.0 \\
6. Mycobacterium phlei & 5.0 \\
7. Mycobacterium smegma & 20.0 \\
8. Mycobacterium 607 & 20.0 \\
9. Mycobacterium avium & 20.0 \\
10. Mycobacterium tuberculosis, H37Rv & 200.0 \\
11. Trichomonas vaginalis, 4F & 12.5 \\
12. Tetrahymena geleii, $\mathrm{W}$ & 50.0 \\
\hline
\end{tabular}

Culture medium : I $\sim 5$, peptone-meat extract agar ; 6 9, peptone-meat extract-glycerol agar ; 10, KIRCHNER $+10 \%$ human plasma; 11 , glucose-peptone-yeast extract $+0.2 \%$ cystein and $10 \%$ human plasma ; 12 , peptone-yeast extract.

End point observed : $1 \sim 9,24$ hours at $37^{\circ} \mathrm{C} ; 10,3$ weeks at $37^{\circ} \mathrm{C} ; 11,2$ days at $37^{\circ} \mathrm{C} ; 12,4$ days at $28^{\circ} \mathrm{C}$. adjusted to various $\mathrm{pH}$ levels ranging from 2.0 to 11.4 with glycine- $\mathrm{HCl}$, phosphate and citrate buffers, and the solu-

Table 7. Stability of kobenomycin solution

tions were heated at $100^{\circ} \mathrm{C}$ for various time lengths. Each sample was diluted with phosphate buffer at $\mathrm{pH} 6.0$ to provide a suitable dilution for assay. The potency of kobenomycin was estimated by the agar cup diffusion method using $B$. subtilis PCI219 as the test organism. The results of $(1,000 \mathrm{mcg} / \mathrm{ml})$ at various $\mathrm{pH}$ levels at $100^{\circ} \mathrm{C}$

\begin{tabular}{r|c|c}
\multicolumn{3}{c}{$(1,000 \mathrm{mcg} / \mathrm{ml})$ at various $\mathrm{pH}$ levels } \\
at $100^{\circ} \mathrm{C}$ \\
\hline \multirow{2}{*}{$\mathrm{pH}$} & Percent activity after heating \\
\cline { 2 - 3 } & 5 minutes & 30 minutes \\
\hline 2.0 & 95.0 & 94.0 \\
5.0 & 95.0 & 90.0 \\
7.0 & 95.0 & 67.5 \\
8.0 & 87.5 & 55.0 \\
11.4 & 50.0 & 16.3 \\
\hline
\end{tabular}


thermostability at various $\mathrm{pH}$ levels are shown in Table 7. It will be seen that greater loss of activity was observed in alkaline solution than in acid.

Acute toxicity in mice: Because kobenomycin is insoluble in water, aqueous solutions of the antibiotic were prepared by the following method: the antibiotic is dissolved in a small amount of dimethylsulfoxide and diluted to the desired concentration with sterile distilled water. Acute toxicity studies were carried out in DS mice weighing $15 \sim 16 \mathrm{~g}$ following 10-day observation period. The antibiotic was found to be toxic to mice by parenteral administration: the $L_{50}$ for mice was $15 \mathrm{mg} / \mathrm{kg}$ given intravenously and $25 \mathrm{mg} / \mathrm{kg}$ given intraperitoneally. Kobenomycin was well tolerated subcutaneously by mice: the $\mathrm{LD}_{50}$ was $>100 \mathrm{mg} / \mathrm{kg}$. It may be that the antibiotic is not well absorbed after subcutaneous injection.

Hemolysis of rabbit erythrocytes: Kobenomycin was serially diluted with dimethylsulfoxide. An equal volume of $\mathrm{pH} 6.0$ phosphate buffer solution was added to each concentration of the antibiotic solvent solution. Hemolytic activity for rabbit erythrocytes was examined by adding $0.5 \mathrm{ml}$ of $3 \%$ cells in saline solution to $0.5 \mathrm{ml}$ of the diluted kobenomycin solvent-phosphate buffer solution. After incubation overnight at $37^{\circ} \mathrm{C}$, the highest dilution producing complete hemolysis was determined. Rabbit red cells were completely lysed by kobenomycin at a concentration of $30 \mathrm{mcg} / \mathrm{ml}$.

\section{Discussion}

On the basis of its physicochemical properties, kobenomycin is clearly a new sulfurcontaining polypeptide antibiotic. It is readily differentiated from the other sulfur-containing polypeptide antibiotics by amino acid composition. Arsimycin $\left.{ }^{4}\right)$ has no aspartic acid, leucine and serine. Leucopeptin ${ }^{57}$ has no leucine and phenylalanine. Cinnamycin ${ }^{6)}$ has no leucine, serine and glycine. Duramycin ${ }^{7)}$ has no leucine and serine, and leucinamycin ${ }^{8)}$ has no serine.

A comparison of the biological properties of kobenomycin and leucinamycin indicates a close similarity between the two. Their antimicrobial spectra are similar, except that kobenomycin has no antifungal activity. The only greater susceptibility of aerobic sporeforming bacilli to kobenomycin and leucinamycin suggests that both new antibiotics might be useful as tools to study spore germination.

\section{References}

1) Nishimura, H. \& K. TAwara : A method for the microscopical observation of Streptomyces using agar-cylinder culture. J. Antibiotics, Ser. A $10: 227,1957$

2) Breed, R. S.; E. G. D. Murray, N. R. Smith \& 94 contributors : Bergey's Manual Determinative Bacteriology. 7 Ed. 1957, The Williams \& Wilkins Company

3) Waksman, S. A. : The Actinomycetes. Vol. 2, 1961, The Williams \& Wilkins Company

4) Reitstötter, J. : Herstellung und Gewinnung des Antibiotikums Arsimycin. German Pat. 1,090,380, Oct. 6, 1960

5) Kondo, S.; M. Sezaki, M. Shimura, K. Sato \& T. HARA : Leucopeptin, a new peptide antibiotic. J. Antibiotics, Ser. A $17: 262 \sim 263,1964$

6) Dyonch, W.; O. L. Shotwell, R. G. Benedict, T. G. Pridham \& L. A. Lindenfelser : Further studies on cinnamycin, a polypeptide antibiotic. Antibiot. \& Chemoth. $4: 1135 \sim 1142,1954$

7) Shotwell, O. L.; F. H. Stodola, W. R. Michael, L. A. Lindenfelder, R. G. Dworschack \& T. G. Pridham : Antibiotics against plant disease. III. Duramycin, a new antibiotic from Streptomyces cinnamomeus forma azacoluta. J. Am. Chem. Soc. $80: 3912 \sim 3915,1958$

8) Mizuno, K.; Y. Ohkubo, S. Yokoyama, M. Hamada, K. Maeda \& H. Umezawa : A new antibiotic, leucinamycin. J. Antibiotics, Ser. A $20: 194 \sim 199,1967$. 